\title{
多発・長期停留した気管支異物症例
}

$$
\text { 三上政弘, 石本 晋一, 田山二 朗 }
$$

\section{Multiple, Long Term Bronchial Foreign Bodies in an Elderly Patient with Chronic Pulmonary Disease}

\author{
Masahiro Mikami, M.D., Shinichi Ishimoto, M.D., and Niro Tayama, M.D. \\ Institution Department of Oto-Rhino-Laryngology, Faculty of Medicine, University of Tokyo, Tokyo
}

Chronic pulmonary disease of the elderly caused by frequent aspiration has been recognized in the recent Japanese literatures. We report an elderly case with cerebrovascular disease who had long-term bronchial foreign bodies and had been treated for "asthma" for years. He was taken to an emergency room because of a dyspnea which occurred at breakfast. Fiberscopy showed a bean-like foreign body in his right main bronchus. Using ventilation bronchoscopy, we removed not only this pulse but a piece of fish vertebra from his right main bronchus and another older one coated by granulation tissue from his left superior lobar bronchus. A chest x-ray of this patient showed a diffusely scattered nodular shadow in the right lower lung field ; this finding resembled that of diffuse aspiration bronchiolitis (DAB). He showed a multiple brain infarct on MR imaging. A low signal-intensity area in the white matter of the left supra orbital gyrus on $\mathrm{T} 1$ weighted image might be related to his characteristic aspiration. We assumed the fine crackle in his lung fields and his continuous productive cough had been caused by frequent aspiration. In the elderly, some patients could have latent aspiration but be incorrectly diagnosed as asthma or other pulmonary diseases. When we meet elderly patients with moist rale and productive cough, we must consider the possibility of chronic pulmonary disease caused by aspiration. There is a need to develop for testing and treating methods for these patients.

Key words : 気管支異物, 慢性嚥下性肺疾患, 脳血管障害, 高齢者

\section{I .はじめに}

高齢化社会の進行に伴い，加齢による嬩下機 能の低下 ${ }^{1)}$, 慢性神経疾患・脳血管障害などによ る老人の誤魷症例の増加が懸念される。気道異 物や繼下性肺炎はもちろんであるが，少量頻回 の誤鮼により引き起こされると考えられる慢性

東京大学医学部耳鼻咽喉科学教室

別刷請求：干113-8655 東京都文京区本郷7-3-1

東京大学医学部耳鼻咽喉科

三上政弘

投稿受付：1998年12月16日
の嬹下性肺疾患の存在が近年指摘されてい $る^{2,3)}$ 。このような症例で, 䛊嬹に気づかれるこ とがないと,いわゆる喘息など他の呼吸器疾患 の診断で漫然と治療されている場合があると考 えられる。今回われわれは気道異物で救急受診 した際, 偶然に長期停留した気管支異物を複数 認め, 習慣性の誤嬹による嚥下性肺疾患が疑わ れた症例を経験したので報告する。

\section{II．症例}

症 例：78歳, 男性

臨床経過：70歳頃より慢性的な湿性咳嗽があ 


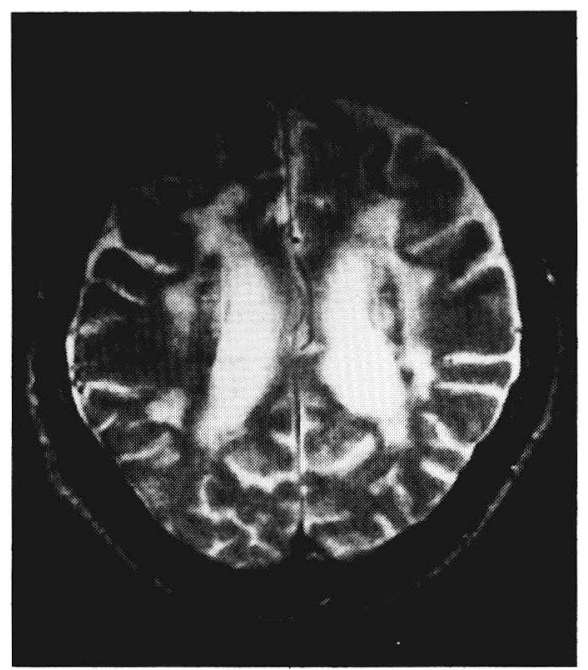

図 1 MRI 2800/90

多発する high intensity area が認められ，いわゆる periventricular leukosis と脳梗塞病変と考えられ る。他のスライスで脳幹部病変を認めなかった。

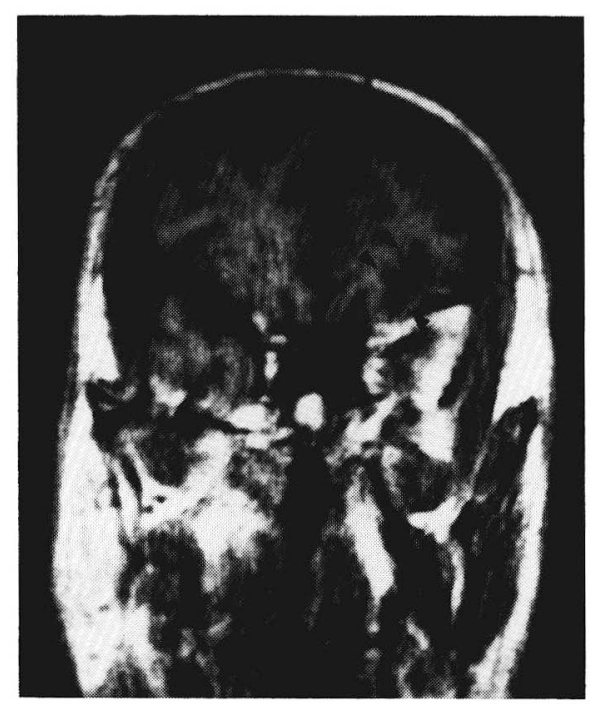

図 2 MRI 600/15

左眼窩回皮質下近傍に不整な low intensity area 認める。

りいわゆる「喘息」と診断されていた。71歳 時, 左半身麻痺が出現し, 当時の MRIにて多発 脳梗塞を指摘されている（図 1, 2)。急性期に 舌の右方偏位が認められたが一過性であり，そ の後明らかな下位脳神経麻痺の症状を残さなか った。72歳時，大豆を誤嚥し呼吸ができなくな
つた，との家族の訴えで救急 (内科) 受診した。 肺雑音 (カルテの記載は “fine crackle”) が聴 取され，吸気時扝よび呼気時の胸部X線が施行 されたが縦隔の偏位はなく，このため異物は明 らかではないとして当日帰宅した。

その後断続的な喀痰喀出のため前出の内科に 通院し，喀痰溶解薬を長期間処方された。家族 によれば，患者は左半身麻痺発症より以前から 失見当識などの軽度の痴呆症状があった。75歳 時，食事中にむせたあと咳が続いているとの訴 えで耳鼻科を受診し緊急入院, 気管支ファイバ 一などにより精査されたが気道に異物は認めら れず, 保存的治療と経過観察の後に退院した。 患者は着替えやトイレなどに介助を要したが， 独力で家族と同じ内容の食事を経口摂取してい た。摂食行動の異常は認めなかった。言語は不 明瞭であったが家族にはある程度理解可能だっ た。

1995年 1 月31日の早朝, 朝食中突如呼吸困難 をきたしたため救急（耳鼻科）受診した。家族 によれば普段から食事は患者一人でとることが 多く, 今回も同席者はなかったため, 誤嚥の有 無および呼吸困難発症直前の食事内容は不明で あった。痴呆のため患者本人からの病歴聴取は 困難であった。

身体および検査所見：来院時全身状態は安定 していたが, 両側全肺野に湿性ラ音を聴取した。 口腔・咽喉頭・頸部に特記所見はなく, 明らか な脳神経麻痺症状を認めなかった。気道異物を 疑い直ちに胸部X線写真を撮影したところ, 吸 気時に縦隔の右方への偏位が認められ, 右主気 管支より末梢の気管支陰影が消失していた。ま た,右下肺野にびまん性の粒状陰影を認めた(図 9 )。呼吸器内科医による気管支ファイバーで は右主気管支内に豆様物質が嵌頓しているのが 認められた。

入院後経過：ファイバー下の異物除去は困難 かつ危険であったため，耳鼻科医により全身麻 酔下に ventilation bronchoscopyを施行した。 右主気管支内にはファイバー上認められていた 豆様物質のほか, 比較的乾燥した魚骨（背骨の 一部）があり，さらに対側では左上葉気管支内 に肉芽に覆われた污穢な魚骨 (背骨の一部) が 認められ,これら 3 つすべてを除去した(図 4 )。 


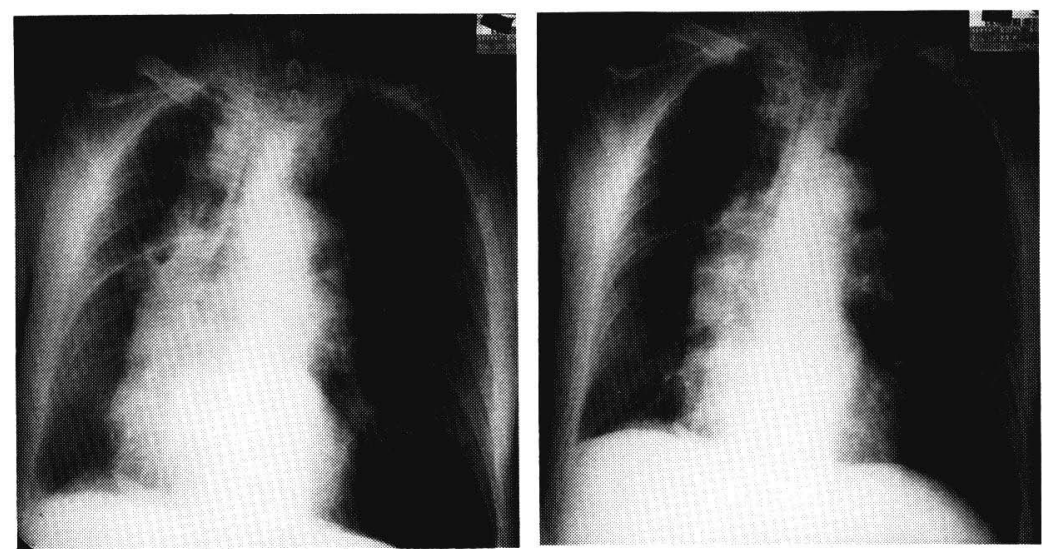

図 3 吸気・呼気での胸部単純X線写真

吸気時の縦隔の右方偏位と, 右主気管支より末梢の気管支陰影

の消失を認める。右下肺野にはびまん性の粒状陰影がある。

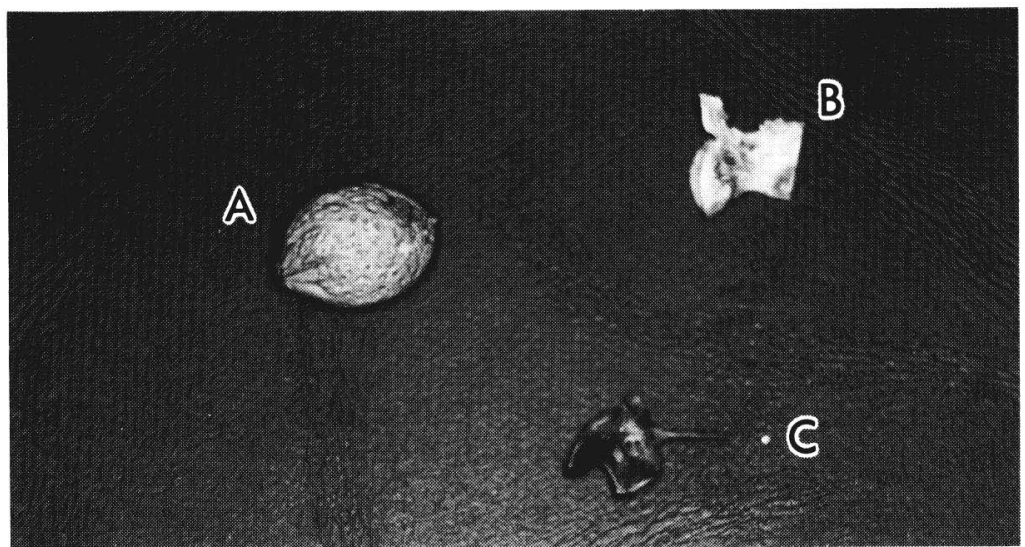

図 4 摘出した気管支異物

$\mathrm{A}$ ：豆様物質。直径約 $1 \mathrm{~cm}$ 。種子様の外観を呈するが何であるかは不明。梅 干しの種子か。 B : 魚骨。背骨の一部。比較的乾燥していた。C：魚骨。背 骨の一部。污穢な粘稠の肉芽様付着物に覆われ, 異物反応と考えられた。

術中これら 3 つ以外の異物を認めなかった。

全身麻酔覚醒後より患者は不穏状態となり， 鎮静剤の投与を必要とした。この一時的な不穏 状態があったことで，家族からすみやかな退院 の希望があり，一過性の症状であること，引き 続いての精査加療の必要性等を説明したものの 結果として理解が得られず，患者は1995年 2 月 2 日退院した。このため下咽頭・食道透視など の検查は施行できなかった。退院時に, 内科で ある在宅医療の主治医に継続治療と, 経口捸取 に関する具体的な管理を文書で依頼した。

\section{III. 考 察}

脳血管障害は核上性嶼下障害の原因として最 多である。脳卒中の急性期には30～50\%に臙下 障害が認められるが多くは軽症・一過性で比較 的予後がよいとされ，慢性期にまで誤嬩が続く 例はそれほど多くはない。そのような症状があ る場合, 脳幹部病変, 両側性の基底核 - 内包病 変による仮性球麻㽻, あるいは口腔, 咽頭, 喉 頭, 脊椎の疾患を合併していることが多いとい われる ${ }^{4,5)}$ 。本症例は, 左半身麻痺発症時に舌の 右への偏位があり, MRI で大脳基底核を含む多 


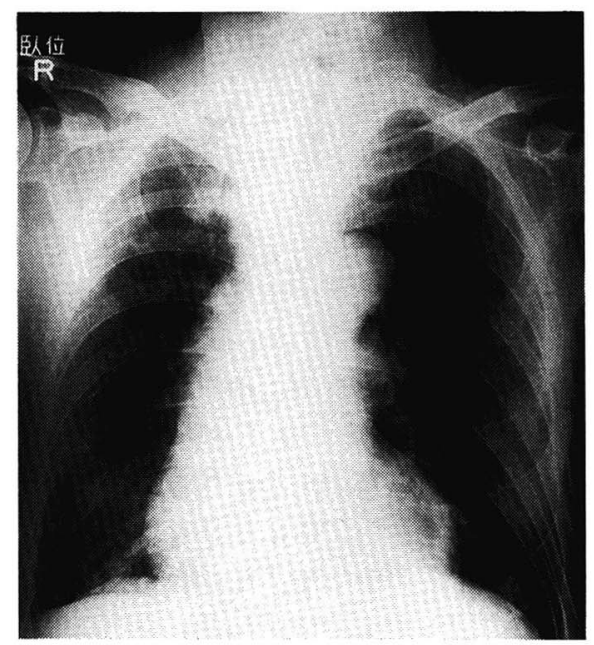

図 5 退院前日の胸部単純 X 線写真

右下肺野を中心に粒状・網状陰影がび漫性に散在し ている。フィルムが保存されている1988年 8 月19日 以来，つねに同様の所見であった。

発脳梗塞が認められたが, 慢性期には理学所見 上の明らかな仮性球麻痺などの脳神経症状を残 さなかった。しかし反復する詋嚥のエピソード は何らかの嬩下障害を推定させる。多発脳梗塞 ももちろん嚥下障害の原因となりうるが，さら に本症例では左半身麻痺発症時の MRI で左眼 窩回皮質下近傍に T1 強調像で low intensity area が認められていた（図 2 )。

両側眼窩回は皮質嬩下領野・咀嚼領野として の役割をもつと考えられている。䜩下の第 2 相 における末梢知覚情報が, 上喉頭神経・舌咽神 経から脳幹部の曣下関連運動ニューロンを順次 駆動し6), 大脳に至るが, 動物実験78) によると両 側眼窩回吻側部領域の神経細胞は延髄の嚥下運 動を形成する神経機構に直接投射し, その状態 に応じて促進あるいは抑制の効果をもたらし， 随意的に開始された嚥下の円滑な反射期への移 行を可能にしていると考えられている。

この動物実験の結果がそのままヒトにあては まるかはまだ確定されてはいないが, 本症例で みられた左眼窩回皮質下近傍の MRI 異常所見 が嬹下運動の反射期への移行を妨げる形で関与 している可能性が考えられる。本症例の度重な る誤嚥の原因としては, 多発脳梗塞・痴呆・加 噛など, 複合的な要因が関与していると考えら
れる。

続いて曣下性肺疾患の可能性について述べ る。本症例では長年の肺雑音と慢性的な湿性咳 嗽が認められていた。今回の胸部X線写真（図 5 ) では右下肺野を中心にびまん性の粒状陰影 を認めている(これは過去の胸部X線所見と同 様であった)。これらの身体およびX線所見は

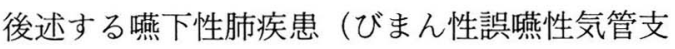
炎）の所見に類似している。つまり，治療に抵 抗する長年の肺雑音と湿性咳嗽は頻回の誤嚥に よる嬹下性肺疾患によるものであった可能性が あり，過去の「喘息」という診断には再検討が 必要である。

近年，慢性嶼下性肺疾患として誤曣性びまん 性汎気管支炎 (誤嬿性 DPB：diffuse panbronchiolitis) ${ }^{2)}$, びまん性誤嚥性気管支炎 (DAB : diffuse aspiration bronchiolitis) ${ }^{3)}$ が 提唱され，対応した症例が報告されるようにな つている。呼吸器科領域のいわゆるびまん性汎 細気管支炎 (DPB) は，両側の呼吸細気管支に 起こるびまん性の慢性炎症により強い呼吸障害 をきたす疾患である。組織学的には, 呼吸細気 管支を中心とした細気管支炎と細気管支周囲炎 で，リンパ球・形質細胞などの円形細胞浸潤や 時にリンパ濾胞・肉芽組織による気管支の閉塞 をみる病態をいう9”。一方誤與性 DPB は, 生前 に誤嚥機会のあった症例の剖検所見において, 肉眼的に DPB と類似する一方で成立機転など が異なる疾患として報告された。この䛊嚥性 DPB の組織学的変化は細気管支領域に散見さ れる肉芽組織で, これら肉芽組織が食物の肉線 維あるいは植物線維などの異物ないし異物型多 核巨細胞などから形成されることが特徵であ り, 細気管支領域の狭窄や閉塞が誤嚥による異 物に起因すると推定されている2)。また，びまん 性誤嚥性気管支炎 (DAB) は, 誤嚥にともなっ て生じたと考えられるびまん性細気管支炎で, 左右両側性で一葉以上に拡がるが誤曣性 DPB よりは比較的小範囲にとどまるものとして提唱 された ${ }^{3)}$ が，筆者には両者の成因に本質的な違 いはなく, 病変の範囲が違うのだと思われる。 誤踑性 $\mathrm{DPB} ・ \mathrm{DAB}$ ともに下肺野に限らず病変 が拡がる理由などその病態は明確には解明され ていないが, 少量頻回の誤嚥の関与, 気道感染 
の関与などが推定されている。欧米にはこれら の概念がなく誤嚥性肺炎の範疇に含められてい ると考えられるが，正しく認識されていない誤 嶼性 DPB および DAB 患者は多数存在すると 推定される。合計1673例の剖検では，その $7 \%$ に嬹下性肺疾患を認めている3)。これらの症例 は聴診所見などから，本症例のように高齢者の 喘息として治療されている可能性がある。

一般的に嬩下障害が生じていることを示唆す る臨床所見として，体重減少，摂取に要する時 間の増加，一口の食物の量の減少，ある種の食 物を避けるようになること，嚥下に際し水分を 欲しがるようになることなどが知られてい る4)。このような患者に誤䜩性 DPBまたは DAB が存在した場合の身体所見で特徴的なの は, 断続的な咳・痰と喘鳴, 胸部の fine crackle で，これらの患者は外来診療上「喘息」と類似 した所見を呈する。検查所見では末梢血で白血 球増加, CRP 陽性を認めることがあるが曣下性 肺炎ほど著明ではない。胸部単純X線では横隔 膜低位とX線透過性の六進, 肺野のびまん性粒 状陰影を認めるとされる。誤嚥性 DPB または DAB の確定診断には嬹下の評価と肺の HR$C T^{10)}$ や組織学的検索も考慮した総合的診断が 必要である。少量頻回の誤嚥が疑われる症例に 関する検査は誤嬹シンチグラムなどが試みられ ているが一般化するに至っていない。

本症例は胸部単純 X線像では肺野にびまん性 の粒状陰影を認め, いわゆる DAB の所見に類 似している。下咽頭・食道透視検查抢よび肺 HR-CT や肺の組織学的検査は施行していない ため診断確定には至らないが, 臨床所見からは 慢性嚥下性肺疾患が強く疑われる。

ところで，気道異物の診断にあたつては，異 物の存在の確認のみならず，存在しないことの 確認も重要である。䛊嚥のエピソードのあと呼 吸状態が一見落ち着いていても, 異物がより末 梢に進むと症状が軽減する場合があり注意を要 する。このため一度の検査で異物が確認できな かった場合でも慎重に経過を観察する必要があ る。本症例の過去 3 回の誤嚥が疑われた際の救 急外来の初診は, 第 1 回目が内科医, 第 2 回目, 第 3 回目はそれぞれ別の耳鼻咽喉科医であっ た。第 1 回目には聴診と胸部X線のみが施行さ
れているが, X線上吸気時に縦隔の偏位がなく, 不透過性の異物も確認できないとして, 外来で の保存的治療を選択している。胸部 X線の所見 がないことが, すなわち気道異物を否定する根 拠にはならず, 異物の疑いのある症例では積極 的に気管支鏡検査を施行すべきであろう。

最後に治療についてであるが, 現在のところ 誤嬩性 DPB および DAB における肺病変の治 療法は誤聼性肺炎の治療に準じる。すなわち原 因となっている誤嚥を除去または改善するこ と，および抗生物質の全身投与と対症療法であ る。例えばアカラジアによる誤嚥が原因となっ た $\mathrm{DAB}$ 症例のような特殊な場合で, 手術によ り誤嚥が軽快したことで肺病変に劇的な改善が 認められた報告がある11)。われわれの症例では 肺雑音と慢性的な湿性咳嗽が，誤嬹による DAB によると推定され, 嘸下に関し, 何らかの 治療を必要とするが,これについては後述する。 誤器性 DPB および DAB の長期予後はいまだ 知られていない。しかし, 進行性の肺機能悪化 が生命予後を短縮することはほぼ自明だと考え られる。

䁵下障害の治療は原因により異なり，リハビ リテーションと各種の外科的治療が行われてい る。本症例は病歴から習慣化した詋嚥が推察さ れるが，嚥下に関する指導・治療は 3 回目の救 急受診までなされておらず, 患者本人が一人で 食事をとっていることが多かった。気道異物に よる窒息, 誤舆性肺炎, 慢性嚥下性肺疾患によ る肺機能の低下などはいずれも生命予後を脅か すであろうことは容易に想像されるため, 本症 例のように頻回の誤嚥が疑われる，もしくは確 実な症例では, 肺病変の治療に加えて経口摂取 の管理が必要である。

一般的な経口摂取の注意点は, 食事の際には 坐位などの安定した姿勢を保ち, 食事に集中さ せる, 一回の嘸下量を調節する, 食事内容を工 夫する, 飲み口の広い器を用い, 食事用の器具 を工夫するなどである。本症例は食事は単独で 摂取しているため，まず家族の監視下におくこ とが必要である。また最初の誤嚥のエピソード は豆類の摂取の際生じており, 今回も豆様物質 が気管支に嵌頓していたことからも，より誤嚥 しにくいものを摂取するように食事の内容に注 
意が必要であろう。

しかしながら, 現実の家庭環境としては毎回 食事を介助する者を確保することは難しいかも しれない。専門家による嚥下訓練も考慮される べきである。嚥下の管理とリハビリ以外の治療 法では，下咽頭・食道透視等の結果によっては 喉頭挙上術や輪状咽頭筋切除術などの機能補助 的な外科的治療も適応となる場合もある。しか し, 本症例のごとく中枢性の嬩下障害では, 嶼 下の全般にわたり障害が生じていることが多 く, 外科治療のみで簡単に改善できるとは言い 難い。さらに本症例は軽度の痴呆症状も加わっ ており，たとえ外科治療が適応となる病態でも 現実の治療は難しい可能性が高い。誤嬩のコン トロールが著しく困難な場合に，気管切開や気 管食道分離術が行われることがあるが，この場 合には発声機能が犠牲となり，もちろん今回は 適応にはならない。

本症例では, 脳梗塞の既往や過去の誤曣の工 ピソード, 断続的な喀疾喀出などから慢性的な 誤嬹とそれによる肺疾患の存在を疑って, 早期 に㫶下の評価と食事の指導がなされるべきであ った。今回は継続した検査・治療を勧めたが家 族の同意を得ることができず，在宅治療の内科 主治医に食事に関して具体的に留意すべき点を 文面により明示し, 今後の治療を依頼した。し かし, 患者および家族を納得させられずに検 查・治療がわれわれ自身の手から離れてしまっ たことは反省すべき点と考えている。

高齢者では特に既往がなくても口腔期の保持 能力・臙下反射・臙下力が低下する例が認めら れており ${ }^{1)}$, 脳血管障害や神経疾患の患者に限 らず，加齢による嚥下能力の低下から, 不顕性 に少量頻回の誤曣が存在する可能性がある。高 齢化社会の進行を迎え, この誤嬹を検出し治療 する方法の開発・普及が期待される。

\section{IV. ま と め}

1）急性期および長期停留気管支異物を複数 認めた多発脳梗塞症例を報告した。

2 ) 本症例の反復する誤嬩の原因として, 多 発脳梗塞・痴呆・加齢による曣下機能低下など, 複合的な要素が推定された。

3 ）動物実験上の嶼下の上位中枢（または皮
質嚥下領野）にあたる左眼窩回皮質下近傍の MRI 異常所見と, 誤嚥との関連について論じ た。

4 ) 本症例では少量頻回の誤嚥による慢性の 鱟下性肺疾患の存在が推定された。

5 ）高齢者の増加にともない嚥下障害患者が 増えると考えられ, 潜在的な噯下性肺疾患の検 查および治療方法の開発普及が必要であると思 われた。

\section{文献}

1）丘村 熙，稲木匠子，森 敏裕・他：高齢者の 嬩下機能一咽頭食道透視よりの観察一。日気食 会報, 42：116-120, 1991 .

2 ) 山中 晃, 斉藤茂樹, 岡本賢三 : 呼吸細気管支 領域の特殊性とその病変の成り立ち.日本臨床, $36: 2427-2433,1978$.

3 ）福地義之助，松瀬 健，木田厚瑞：びまん性曣 下性細気管支炎の臨床。日胸疾会誌，27：571577, 1989.

4 ) Wiles, C.M. : Neurologic dysphagia. J. Neurol. Neurosurg. Psychiatry, 54:1037-1039, 1991.

5 ) 森 栄二, 木村彰男, 才藤栄一・他：脳卒中早 期リハビリテーションの実際 (2)一䁵下障害へ のアプローチー．総合リ八, 18：935-938, 1990.

6 ) Umezaki, T., Matsuse, T., and Shin, T.: Neuronal organization of swallowing in the cat medulla oblongata. Inoue, T., et al. (eds), Recent Advances in Bronchoesophagology, pp. 375-376, Elsevier Science Publishers, Amsterdam, 1990.

7 ) Matsuse, T., Umezaki, T., and Shin, T. : Cortical projections to the medullary swallowing center in the cat. Inoue, T., et al. (eds), Recent Advances in Bronchoesophagology, pp. 373-374, Elsevier Science Publishers, Amsterdam, 1990.

8 ) Nakamura, Y., Kubo, Y., Nozaki, S., et al. : Cortically induced masticatory rhythm and its modification by tonic peripheral inputs in immobilized cats. Bull. Tokyo Med. Dent. Univ., 23 : 101-107, 1976.

9 ) 本間日臣, 本間行彦，田村昌士・他：厚生省特 定疾患間質性肺炎疾患調査研究班, 昭和 55 年度 研究報告書, 1980 .

10）野間恵之，何澤信礼，小林勝弘・他：びまん性 誤嚥性細気管支炎（DAB： diffuse aspiration bronchiolitis) の HRCT 像。臨床放射線，41： 129-133, 1996.

11）野間恵之, 黒田康正, 高森庸江・他：食道アカ ラジアに伴ったびまん性誤䍛性細気管支炎 (DAB)の 1 例. 臨床放射線, $40 ： 859-862,1995$. 